REVIEW

\title{
Mechanical properties of biofiber/glass reinforced hybrid composites produced by hand lay-up method: A review
}

\author{
Moham Ed Abdur Razzaq ${ }^{1}$ Sababa Erfan Moma ${ }^{1}$ Md Sanaul Rabbi ${ }^{*}$ \\ ${ }^{1}$ Department of Mechanical Engineering, Chittagong University of Engineering and Technology, Chattogram-4349, Bangladesh
}

\section{Check for updates}

Correspondence to: Md Sanaul Rabbi, Department of Mechanical Engineering, Chittagong University of Engineering and Technology, Chattogram-4349, Bang- ladesh; Email: rabbi@cuet.ac.bd

Received: July 29, 2021;

Accepted: September 28, 2021;

Published: October 2, 2021.

Citation: Razzaq MEA, Moma SE and Rabbi MS Mechanical properties of biofiber/glass reinforced hybrid composites produced by hand lay-up method: A review. Mater Eng Res, 2021, 3(1): 144-155. https://doi.org/10.25082/MER.2021.01.003

Copyright: () 2021 Rabbi et al. This is an open access article distributed under the terms of the Creative Commons Attribution License, which permits unrestricted use, distribution, and reproduction in any medium, provided the original author and source are credited.

\begin{abstract}
Hybrid composites utilize more than one kind of strands within the same matrix to urge the synergistic impact of both fibers' properties on composites' general properties Hybridization can be performed from artificial, natural, and a combination of both fibers. The constituent filaments can be altered in numerous ways, driving to the variety in composite properties. Partial substitution of glass fiber with natural ones offers an advantage compared with glass fiber composites while permitting to obtain a mechanical performance higher than using pure natural fiber composites. Recently, researchers are tending towards the development of hybrid composites which will provide good static properties. In this context, a concise review has been done on the recent developments of natural/glass fiber-reinforced composites made by hand lay-up method. It includes a survey of the past research already available involving the hybrid composites and the effect of various parameters on composites' performance studied by various researchers.
\end{abstract}

Keywords: natural fiber, glass fiber, hand lay-up, mechanical properties

\section{Introduction}

Composite materials consist of two or more physically distinct phases whose combination produces aggregate properties different from those of its constituents [1] . Two significant types of fibrous materials are available: synthetic fiber and natural fiber, to enhance the properties of polymer [2] . After completion of the product life cycle, synthetic fiber-based composites show several demerits such as their recycling, reusability, and biodegradability [3] . Such properties are inevitable for sustainability in terms of environmental sensitivity. Due to these reasons, the concept of using natural fiber as the viable alternative of synthetic fiber was introduced [4] . Hybridization of the natural fiber (jute, sisal, banana, bamboo etc.) and synthetic fiber (glass, carbon, kevlar etc.) in the same matrix (thermoplastic or thermosets) is the only ways to take the best advantage from both fibers' following develop a superior but economical composite [5] - Attainment of balance in physical properties along with design flexibility is the significant advantages of hybrid composite [6] . Among various synthetic fibers, glass, carbon, and aramid, most of the researcher conducted their research on glass fiber-based hybrid composites. Physical properties of raw natural fibers, reported by researchers are listed in Table 1.

The hybrid fiber reinforced polymer composites can be manufactured by adopting various manufacturing techniques such as- hand lay-up, compression molding, injection molding, autoclave, and Vacuum Assisted Resin Transfer Molding (VARTM) process [21-23] . In order to get the desired mechanical properties of the composites, various types of matrix are usually used in hand lay-up technique. Significant mechanical properties of commonly used glass fiber and polymers are listed in Table 2.

Hand lay-up is a molding approach wherein reinforcements (woven, knitted, stitched, or bonded fabrics) are positioned by way of hand, and then polymer resin is poured or sprayed at the fiber. The present study provides a rigorous overview of recent research works conducted on natural fiber/glass biocomposites fabricated by hand lay-up techniques. Along with the brief description stated in the literature, corresponding significant mechanical properties are listed in tables. Section 2 discussed the mechanical properties investigations by the numerous researchers of mono fiber reinforced hybrid composites. Properties assessed for multi fiber reinforced biocomposites are analyzed in Section 3. Finally, concluding remarks are stated in Section 4. 
Table 1 Mechanical properties of commonly used natural fiber as reinforcement in biocomposites

\begin{tabular}{|c|c|c|c|c|c|c|}
\hline Fiber & Density $\left(\mathrm{g} / \mathrm{cm}^{3}\right)$ & Diameter $(\mu \mathrm{m})$ & Tensile strength (MPa) & Young's Modulus (GPa) & Elongation at break (\%) & Reference \\
\hline Sisal & 1.45 & $50-200$ & $468-640$ & $9.4-22.0$ & 3-7 & [7] \\
\hline Bamboo & - & $10-330$ & 440 & - & 1.4 & [8] \\
\hline Jute & 1.3 & 25.2 & $393-773$ & 26.5 & $1.5-1.8$ & [9] \\
\hline Coir & $1.15-1.46$ & $10-46 \mathrm{~mm}$ & $95-593$ & $2-8$ & $15-51.4$ & [10] \\
\hline Kenaf & $1.2-1.4$ & - & - & 20 & $9.1-12.3$ & [11] \\
\hline Palmyra & 1.2 & $300-320$ & $276 \pm 5$ & $8.9 \pm 1.2$ & 3.08 & [12] \\
\hline Flax & $1-1.5$ & $160-230$ & $40-150$ & $60-80$ & $4.5-6.5$ & [13] \\
\hline Banana & 1.35 & - & 212 & 8 & 2 & [14] \\
\hline Oil Palm & $0.7-1.55$ & $50-500$ & $100-400$ & $1-9$ & $8-18$ & [15] \\
\hline Kapok & $0.38-1.47$ & 22.65 & $45-64$ & $1.7-2.4$ & $2-4$ & [16] \\
\hline Silk & $1.3-1.38$ & - & $650-750$ & .016 & $18-20$ & [17] \\
\hline Hemp & $1.4-1.6$ & $270-900$ & $200-1040$ & $23.5-90$ & $1-3.5$ & [18] \\
\hline Pineapple & 1.52 & - & 413 & 34 & 1.6 & [14] \\
\hline Sugar Palm & - & $99-311$ & 190.29 & 3.69 & 19.6 & [19] \\
\hline Basalt & 2.7 & - & 4840 & 89 & 3.15 & [20] \\
\hline
\end{tabular}

Table 2 Mechanical properties of commonly used glass fibers and polymers for composite fabrication using hand lay-up method

\begin{tabular}{lccccc}
\hline Matrix & $\begin{array}{c}\text { Density } \\
\left(\mathrm{g} / \mathrm{cm}^{3}\right)\end{array}$ & $\begin{array}{c}\text { Tensile } \\
\text { strength } \\
(\mathrm{MPa})\end{array}$ & $\begin{array}{c}\text { Elastic } \\
\text { Modulus } \\
(\mathrm{GPa})\end{array}$ & $\begin{array}{c}\text { Elongation } \\
\text { at break } \\
(\%)\end{array}$ & Reference \\
\hline E-glass & 2.5 & $2000-3500$ & 70 & $2.5-3.0$ & {$[24]$} \\
S-glass & 2.5 & 4570 & 86 & 2.8 & {$[24]$} \\
Epoxy & $1.1-1.4$ & $35-100$ & $3-6$ & $0.8-6$ & {$[25]$} \\
Polyester & 1.16 & $8-19$ & 0.58 & 1.6 & {$[7]$} \\
Unsaturated Polyester (USP) & 1.2 & 61 & 4 & 2.5 & {$[9]$} \\
\hline
\end{tabular}

\section{Mono fiber reinforced hybrid biocomposites}

\subsection{Sisal fiber}

Sisal/Glass (S/G) epoxy biocomposites with fiber weight ratio 1:1 shows maximum tensile, flexural and compressive strength where the fiber length was $2 \mathrm{~cm} \mathrm{[26]} \mathrm{.} \mathrm{Alkali} \mathrm{treated} \mathrm{sisal} \mathrm{fiber}$ with $2 \mathrm{~cm}$ of length provided maximum strength [27] and it was reported that such specimen is more chemically resistant [28] . Characterization of silane treated S/G composite showed significantly superior tensile property [29-32] . Mechanical properties of the S/G unsaturated polyester biocomposites with the addition of chalk powder (as additive) decreases with the increasing of the chalk powder quantity [33,34]. Hashmi et al. [35] assessed the properties of various sequenced S/G epoxy (chopped strand mat) composites and concluded that sisal paper could replace $84.5 \%$ of glass fiber to obtain an equivalent tensile modulus range. Palanikumar et al. [36] analyzed the fiber distribution (transverse and longitudinal) effects on the mechanical properties.

\subsection{Bamboo fiber}

Bamboo/glass (B/G) combination (4 layers) in the epoxy matrix improves the tensile strength [37]. The mechanical properties and water absorption behaviour of strand glass mat, woven glass mat reinforced epoxy, and polyester biocomposites were studied by Kushwaha \& Kumar [38] . The epoxy matrix showed better tensile characteristics (increase of 19\%) result than polyester matrix (increase of 15\%) while reinforced with woven bamboo mats. Retnam et al. [39] investigated that the hybrid specimen with $\pm 45^{\circ}$ orientation yielded better mechanical (tensile, flexural and impact strength) properties. Vaghasia \& Rachchh [40] prepared B/G unsaturated isopththalic polyester hybrid composites and it was found that the samples with $9 \%$ bamboo fiber showed best tensile, flexural and hardness properties.

\subsection{Jute fiber}

Jute/Glass (J/G) epoxy composites perform better for flexural loading (1.03 kN) [41] . Optimum tensile behavior of $\mathrm{J} / \mathrm{G}$ epoxy composites were found for $30 \mathrm{wt} \%$ of jute fiber [42] Gujjala et al. [43] prepared $\mathrm{J} / \mathrm{G}$ composite specimens where the jute fiber direction varies $\left(+45^{\circ}\right.$ to $-45^{\circ}$ ) and studied the mechanical properties. Hybrid $\mathrm{J} / \mathrm{G}$ composites with higher number of layers $(10,17,18)$ were studied to analyze the mechanical properties $[44,45]$. The addition 
of $16.5 \mathrm{wt} \%$ glass fiber in a total fiber weight fraction of $42 \%$ enhances the tensile, flexural, and interlaminar shear strength (ILSS) by $37,31.23$, and $17.6 \%$ respectively of $\mathrm{J} / \mathrm{G}$ isothalic polyester composites [46] . Addition of fly ash in J/G epoxy samples enhances the tensile and flexural properties [47]. Trehan et al. [48] investigated that the alkali treatment, mixing and curing time did not significantly influence the tensile and flexural strength of $\mathrm{J} / \mathrm{G}$ polyester composites. Mechanical properties of UV treated biocomposites were studied by Kafi et al. [49]

\subsection{Coir fiber}

Jayabal et al. assessed the effect of different stacking sequences on mechanical properties of woven C/G unsaturated polyester composites $[50,51]$ and GGC and CGG combination showed maximum strength. $\mathrm{C} / \mathrm{G}$ specimens with untreated coir fiber of $15 \mathrm{~mm}$ enhanced the mechanical properties [52] . Results concluded that surface modification of fiber, short, less/optimum fiber loading would give less water absorption, good mechanical properties, and exhibits good performances in normal conditions [53] . Untreated coir fiber length of $20 \mathrm{~mm}$ and fiber loadings of $40 \mathrm{wt} \%$ with an increase in the glass fabric content from 0 to $100 \%$ of $\mathrm{C} / \mathrm{G}$ composites exhibit improved strength from 37 to $350 \%$ and for treated fiber, the strength improved by 50 to $313 \%[54]$.

\subsection{Kenaf fiber}

Ramesh [11] showed that K/G composites exhibits higher tensile and impact strengths for the specimen contains $90^{\circ}$ fiber orientation whereas $0^{\circ}$ fiber oriented product showed flexural strength. Woven K/G unsaturated polyester composites of higher number (7) of layers with $3 \mathrm{GK} 3 \mathrm{G}$ combination provided better performances $[55,56]$. Fatigue properties were also examined by Sharba et al. [57] . Rozali et al. [58] reported that GKG unsaturated polyester biocomposites exhibits maximum flexural properties. On a contrary, KGK combination resulted in the highest water uptake and thickness swelling.

\subsection{Palmyra fiber}

Velmurugan \& Manikandan [59] characterized the randomly mixed Palmyra/Glass (Pa/G) rooflite resin composites (disperse \& skin-core type) and estimated optimum fiber length. Sravya \& Sivaganesan [60] also reinforced $\mathrm{Pa} / \mathrm{G}$ into the epoxy resin keeping Resin-fiber ratio at 90/10 $\%$, while $\mathrm{Pa} / \mathrm{G}$ fiber ratio was varied like $25 / 75 \%, 50 / 50 \%, 75 / 25 \%, 100 / 0 \%$. Shanmugam et al. [12] found an increase of 33\% in tensile, 55\% flexural, and 50\% in impact strength for benzoyl, permanganate, and alkali-treated bi-layer $\mathrm{Pa} / \mathrm{G}$ composites, respectively, compared to untreated fiber composites. Karthikeyan et al. [61] prepared two specimens (15wt\% / 10wt $\%$ and vice-versa) of $\mathrm{Pa} / \mathrm{G}$ epoxy composites by varying the fiber weight ratio where epoxy percentages were $75 \%$ for both samples. Specimen with $15 \mathrm{wt} \%$ showed the best performance compared to others.

\subsection{Flax fiber}

Meenakshi \& Krishnaoorthy [62] reported that Flax/Glass (F/G) polyester composites showed equally good properties to conventional glass fiber composite and outperform the mono natural fiber composite. Santulli et al. [63] studied emphasized on the need to control void content and defects for better performance of F/G epoxy composites. Gupta [64] investigated the static behavior of F/G biocomposites and reported that the lay-up sequence GFGH was better than the FGFH arrangement in terms of tensile, flexural, compressive, and impact properties. Kumar et al. [65] determined the properties of 8-layered F/G epoxy composites. Ramesh [13] conducted the SEM analysis of F/G epoxy composites and reported that the specimens with $0^{\circ}$ fiber orientation outperformed that of $90^{\circ}$ fiber orientation. Interlaminar and sandwich structures comprising F/G sheets were used by Wang et al. [66] to study the lamination method's effect on properties.

\subsection{Banana fiber}

Joseph et al. [67] studied the enhancement of the physical properties of Banana/Glass $(\mathrm{Ba} / \mathrm{G})$ phenol-formaldehyde $(\mathrm{PF})$ composites keeping total volume fraction constant $(0.4)$ The maximum tensile properties were found for a vivid combination of both fiber, Tensile and impact properties of $\mathrm{Ba} / \mathrm{G}$ polyester biocomposites were investigated by Pothan et al. [68] considering the volume fraction variation of glass fiber $(0.03,0.07,0.11,0.15,0.16,0.17)$ Batu \& Lemu [69] fabricated $\mathrm{NaOH}$ treated false $\mathrm{Ba} / \mathrm{G}$ epoxy composites and sample with 
volume fraction ratio 0.4 showed the highest strength. A selected length of $15 \mathrm{~mm} \mathrm{NaOH}$ treated $\mathrm{Ba} / \mathrm{G}$ epoxy composites showed an increase in banana fiber composition increases the high displacement to tensile load [70] .

\subsection{Hemp fiber}

Bhoopathi [18] and Prashanth et al. [71] fabricated Hemp/Glass (H/G) epoxy composites to evaluate various properties. Nano clay was used in the hybrid preparation to improve the composites' properties [72] . Shahzad [73] assessed the impact and fatigue properties of H/G polyester biocomposites.

\subsection{Pineapple fiber}

Pineapple/Glass $(\mathrm{P} / \mathrm{G})$ polyester composites was fabricated considering a constant volume fraction of fiber (P/G: 30\%/70\%) and analyzed the static [48] , dynamic mechanical properties [74] , and thermo-physical properties [75] . Mishra et al. [7] figured out the influence of various chemical treatments (Alkali, cyanoethylation) on $\mathrm{P} / \mathrm{G}$ polyester composites' properties. Curaua fiber belongs to the pineapple plant family. Silva et al. [76] evaluated the mechanical properties degradation of curaua/glass hybrid composites due to water absorption. Water absorption of the composite was higher for distilled water (2.10\%) than for seawater (1.95\%). Samples exposed to distilled water showed superior tensile properties.

\subsection{Kapok fiber}

Reddy et al. [77] fabricated Kapok/Glass (Ka/G) polyester hybrid composites by varying the fiber ratio as 1:0, 3:1, 1:1, 1:3, and 0:1 and by keeping total fiber loading fixed at 9 vol.\%. The flexural, compressive, and interlaminar shear resistance and hardness and tensile properties and impact properties of alkali-treated and untreated $\mathrm{Ka} / \mathrm{G}$ composite samples were analyzed [78-80] . The $\mathrm{Ka} / \mathrm{G}$ fiber ratio 1:3 gave optimum results in flexural, compressive, tensile, and hardness properties.

\subsection{Silk fiber}

Priya et al. [81] (Priya, 2006) experimented on Silk/Glass (Si/G) composite and evaluated the strength of the product. Within the sample, total fiber content was $25 \%$, whereas investigation was made on the context of glass fiber. It was found that, at the fiber ratio of 50/50 the strength seemed to have almost doubled. Yang et al. [82] fabricated three groups of Si/G unsaturated polyester composites with small, medium and large fiber crepe to investigate the optical and mechanical properties and the investigated result reveals that the lamination structure does influence on the flexural property.

\subsection{Sugar palm fiber}

Sapuan et al. [19] fabricated Sugar palm/Glass ( $\mathrm{Su} / \mathrm{G})$ reinforced unsaturated polyester composite for various fiber weight ratios $(\mathrm{Su} / \mathrm{G}=4: 0,4: 1,4: 2,4: 3,4: 4$, and 0:4) and characterized the specimen with respect to the fiber content. Among all samples, the 4:4 weight ratio exhibits the best result. The influence of chemical modification (Benzoylation) on flexural and compressive properties of $\mathrm{Su} / \mathrm{G}$ epoxy hybrid composites were evaluated by Safri et al. [83] . They varied the $\mathrm{Su} / \mathrm{G}$ ratio as 100:0, 70:30, 50:50, 30:70 and 0:100. Composition of 30:70 held the best flexural and compressive properties.

\subsection{Basalt fiber}

Sapuan et al. [84] investigated the physical properties of Basalt/Glass (Bas/G) unsaturated polyester biocomposites where longitudinal basalt fiber was used. Among all wt \%, combination Bas22.5/G7.5 sample depicted optimum properties. Bas/G polyester composites characterization for various layering arrangement was reported by Patel et al. [85] . Sample with the mix stacking sequence showed better properties than plain basalt and plain glass polyester composite.

\section{Multiple fiber reinforced hybrid biocomposites}

Ramesh et al. [86, 87] evaluated that the $\mathrm{S} / \mathrm{J} / \mathrm{G}$ polyester samples with $0^{\circ}$ fiber direction performed better than that of $90^{\circ}$ oriented samples. Ramnath et al. [88,89] figured out the influence of fiber orientation and composition variation on the mechanical properties with the volume fraction of the up to 0.40 . It was found that the flexural modulus exhibits highest value. 
The sample having a more significant percentage of abaca content with $45^{\circ}$ fiber orientations resulted in optimum tensile and flexural properties. Study reported that the B/J/G reinforced epoxy composites shows better ultimate strength, flexural stiffness, percentage of elongation, and ultimate shear strength than B/G or J/G composites [90] . Rajesh \& Pitchaimani [91] analyzed the $\mathrm{B} / \mathrm{J} / \mathrm{G}$ polyester biocomposites where glass fiber was used in woven format and natural fiber as the mat form. Results revealed that such hybridization enhances the impact and damping properties significantly rather than on tensile and flexural properties. Parandaman et al. [92] assessed the characteristics of B/J/G epoxy composites. Chandramohan et al. [93] examined the mechanical properties, water absorption resistance, and abrasion response of $\mathrm{B} / \mathrm{J} / \mathrm{G}$ polyester matrix with a fiber matrix ratio of 50:50. The maximum tensile, flexural, impact, and shear values were found for GBJBJG stacking combination. Pani et al. [94] fabricated six-layered biocomposites with fiber and epoxy ratio maintained $35 \%: 65 \%$. The $[\mathrm{G} / \mathrm{B} / \mathrm{J}]_{s}$ specimen followed by the degradation of its flexural properties (strength by $42 \%$ and modulus by $33 \%$ ). Bhoopathi et al. [95-97] characterized the $\mathrm{Ba} / \mathrm{H} / \mathrm{G}$ epoxy composites with and without the fiber chemical treatment where untreated combination revealed the maximum flexural and impact properties. Chaithanyan et al. [98] prepared C/S/G reinforced isophthalic polyester composites on a volume fraction basis of $0.4 \& 0.5$ and determined their mechanical properties. The breaking load of $\mathrm{S} / \mathrm{G}$ biocomposites is $110 \%$ times greater than $\mathrm{S} / \mathrm{C} / \mathrm{G}$ composite. $\mathrm{A} / \mathrm{Ba} / \mathrm{G}$ bisphenol composites exhibit better flexural strength [99] and $\mathrm{A} / \mathrm{Ba} / \mathrm{G}$ reinforcement in resin of Ortho-Phthalic acid shows better tensile modulus [100] . Ramnath et al. [90] fabricated and characterized J/F/G composites and it was found that the specimens had excellent properties under tensile, flexural loading. H/F/G epoxy composites resulted better mechanical properties than J/G, H/G, F/G, $\mathrm{J} / \mathrm{H} / \mathrm{G}$, and $\mathrm{H} / \mathrm{F} / \mathrm{G}$ epoxy composites [101] . Study on J/P/G epoxy composites revealed that the tensile and flexural properties were increased with the higher fiber content [102,103].

Table 3 and Table 4 lists the significant mechanical properties of mono biofiber/glass fiber and multiple fiber reinforced hybrid composites, respectively.

Table 3 Reported works on mechanical properties of mono fiber/glass fiber reinforced polymer hybrid composites

\begin{tabular}{|c|c|c|c|c|c|c|c|c|c|c|}
\hline Fiber & Matrix & $\begin{array}{c}\text { Tensile } \\
\text { strength } \\
(\mathrm{MPa})\end{array}$ & $\begin{array}{c}\text { Tensile } \\
\text { Modulus } \\
(\mathrm{GPa})\end{array}$ & $\begin{array}{c}\text { Flexural } \\
\text { strength } \\
(\mathrm{MPa})\end{array}$ & $\begin{array}{c}\text { Flexural } \\
\text { Modulus } \\
(\mathrm{GPa})\end{array}$ & $\begin{array}{l}\text { Impact } \\
\text { strength }\end{array}$ & $\begin{array}{l}\text { Elongation } \\
\text { at break } \\
(\%)\end{array}$ & $\begin{array}{c}\text { Micro } \\
\text { Hardness }\end{array}$ & Reference & $\begin{array}{c}\text { Related } \\
\text { Research(s) }\end{array}$ \\
\hline \multirow{3}{*}{ Sisal } & Epoxy & 185.25 & - & 232.65 & - & $15.7\left(\mathrm{~J} / \mathrm{m}^{2}\right)$ & - & - & {$[37]$} & [104] [26] [27] [28] [35] \\
\hline & USP & 30.26 & - & 76.78 & 3.78 & $5.76(\mathrm{~J} / \mathrm{m})$ & 8.2 & - & [29] & - \\
\hline & Polyester & 101 & - & $139 \mathrm{MPa}$ & - & $148(\mathrm{~J} / \mathrm{m})$ & - & - & {$[105]$} & - \\
\hline \multirow{3}{*}{ Bamboo } & Epoxy & 93 & 5.3 & 160 & 6.5 & - & - & 23.4 & [106] & [37] [107] \\
\hline & Polyester & 243 & 10.75 & - & & - & - & - & [77] & - \\
\hline & UIP & 108 & 0.75 & 255 & $760.2 \mathrm{MPa}$ & - & - & 48.5 & [40] & - \\
\hline \multirow{3}{*}{ Jute } & Epoxy & 82 & 4.8 & 130 & 6.4 & - & - & - & {$[43]$} & {$[86][70][45][47][108][109]$} \\
\hline & USP & 32 & 1.85 & - & - & $40\left(\mathrm{~kJ} / \mathrm{m}^{2}\right)$ & - & - & [49] & {$[9]$} \\
\hline & Polyester & 125 & 12.5 & 160 & 12.5 & - & - & - & [44] & [48] \\
\hline \multirow{3}{*}{ Coir } & Epoxy & 17 & 1.8 & 62 & - & - & - & 22 & [52] & [53] \\
\hline & USP & 49.4 & 1.45 & 71.4 & 2.88 & $97.5\left(\mathrm{~kJ} / \mathrm{m}^{2}\right)$ & 12.5 & - & [50] & [51] \\
\hline & Phenolic Resin & 33.63 & 6.97 & 170 & 9.75 & - & - & - & [65] & - \\
\hline \multirow{2}{*}{ Kenaf } & Epoxy & 69.86 & - & 162.566 & - & $6.66(\mathrm{~J})$ & - & - & [87] & - \\
\hline & USP & 195 & 95 & 275 & 195 & - & 2 & - & {$[55]$} & [56] [57] [58] \\
\hline \multirow{3}{*}{ Palmyra } & USP & 57.53 & 2.26 & 91 & 17.23 & $29.49\left(\mathrm{~kJ} / \mathrm{m}^{2}\right)$ & - & - & {$[12]$} & - \\
\hline & IRR & 138 & 4.80 & 245.56 & 8.47 & $10.80\left(\mathrm{~J} / \mathrm{cm}^{2}\right)$ & - & - & [110] & - \\
\hline & Rooflit Resin & 26.3 & 1.31 & 39.85 & 1.34 & $1.76\left(\mathrm{~J} / \mathrm{cm}^{2}\right)$ & 3.2 & - & [59] & - \\
\hline \multirow{2}{*}{ Flax } & Epoxy & 82.71 & - & 143.99 & - & $4\left(\mathrm{~kJ} / \mathrm{m}^{2}\right)$ & - & - & {$[13]$} & {$[64][65][66][63]$} \\
\hline & Polyester & 83.75 & - & 83.75 & - & $14.33(\mathrm{~J} / \mathrm{m})$ & - & - & {$[62]$} & - \\
\hline \multirow{2}{*}{ Banana } & Epoxy & 132 & 1.35 & 165.5 & - & - & - & - & [69] & [111] [70] \\
\hline & Polyester & 98 & 1.89 & - & - & $84\left(\mathrm{~kJ} / \mathrm{m}^{2}\right)$ & - & - & [68] & - \\
\hline \multirow{3}{*}{ Oil palm } & Epoxy & 83 & 2.1 & - & - & $80\left(\mathrm{~kJ} / \mathrm{m}^{2}\right)$ & 6.4 & - & {$[112]$} & - \\
\hline & $\mathrm{PF}$ & 90 & 2.7 & 99 & 0.95 & $220(\mathrm{~kJ} / \mathrm{m})$ & 6.3 & - & [15] & - \\
\hline & Polyester & 58 & 4.8 & 105 & 7.4 & $16\left(\mathrm{~kJ} / \mathrm{m}^{2}\right)$ & 3.0 & $115.5 \mathrm{HRB}$ & [113] & [114] [115] \\
\hline Hemp & Epoxy & 39.3 & - & $0.32 \mathrm{KN}$ & - & $6.45(\mathrm{~J})$ & - & - & [71] & [18] [72] \\
\hline Pineappale & Polyester & 102.1 & 2.73 & - & - & $1150(\mathrm{~J} / \mathrm{m})$ & 5.8 & - & {$[48]$} & {$[74][75][105]$} \\
\hline Kapok & Polyester & 107 & 2.36 & 222.5 & 12.55 & $14.7(\mathrm{~J} / \mathrm{m})$ & - & $124 \mathrm{HRB}$ & {$[?, ?]$} & - \\
\hline Silk & Epoxy & 84.04 & 1.0 & 115 & 5.40 & - & 14.33 & - & [81] & [82] \\
\hline \multirow{2}{*}{ Sugar Palm } & USP & 61.69 & 8.12 & 151.34 & 7.28 & $4.90\left(\mathrm{~kJ} / \mathrm{m}^{2}\right)$ & 1.36 & - & [19] & - \\
\hline & Epoxy & - & - & 56.93 & 3.57 & $15(\mathrm{~J})$ & & & [83] & \\
\hline Basalt & Polyester & 270 & 7.10 & 946.46 & 44.89 & - & 2.35 & - & [84] & {$[85]$} \\
\hline
\end{tabular}

Notes: UIP = Unsaturated Isopththalic Polyester; IRR = Isophthalic Rooflit Resin; PF = Phenol Formaldehyde 
Table 4 Reported works on mechanical properties of multiple fiber/glass fiber reinforced hybrid polymer composites

\begin{tabular}{|c|c|c|c|c|c|c|c|c|}
\hline Fiber & Matrix & $\begin{array}{c}\text { Tensile } \\
\text { strength } \\
(\mathrm{MPa})\end{array}$ & $\begin{array}{l}\text { Tensile } \\
\text { Modulus } \\
(\mathrm{GPa})\end{array}$ & $\begin{array}{c}\text { Flexural } \\
\text { strength } \\
(\mathrm{MPa})\end{array}$ & $\begin{array}{c}\text { Flexural } \\
\text { Modulus } \\
(\mathrm{GPa})\end{array}$ & $\begin{array}{l}\text { Impact } \\
\text { strength }\end{array}$ & $\begin{array}{c}\text { Elongation } \\
\text { at break } \\
(\%)\end{array}$ & Reference \\
\hline Sisal/Jute & Polyester & 232.12 & - & 308.56 & - & $18(\mathrm{~J})$ & 14.4 & [87] \\
\hline Sisal/Jute & Epoxy & 23.29 & 2.08 & 59.80 & 3.14 & $15.01\left(\mathrm{~kJ} / \mathrm{m}^{2}\right)$ & - & [92] \\
\hline Abaca/Jute & Epoxy & 57 & 0.29 & 12.1 & 1.45 & $12(\mathrm{~J})$ & 18.182 & [88] \\
\hline Banana/Jute & Epoxy & 42.24 & 2.65 & 72.93 & 4.70 & $26.35\left(\mathrm{~kJ} / \mathrm{m}^{2}\right)$ & - & [92] \\
\hline Banana/Jute & Polyester & 25.4 & 0.604 & 15.6 & 1.215 & $500(\mathrm{~J} / \mathrm{m})$ & - & [91] \\
\hline Bamboo/Jute & Polyester & 78.86 & 3.581 & 133.68 & 2.75 & $24.59(\mathrm{~J})$ & - & [93] \\
\hline Banana/Hemp & Epoxy & 62.34 & - & 1.25 & - & $10(\mathrm{~J})$ & - & [97] \\
\hline Coir/Sisal & IP & 65 & .360 & 132.15 & 0.99 & $1.4\left(\mathrm{~kJ} / \mathrm{m}^{2}\right)$ & 34 & [98] \\
\hline Banana/Abaca & Bisphenol-A & 57.32 & .325 & 106.82 & 0.433 & $0.922\left(\mathrm{~kJ} / \mathrm{m}^{2}\right)$ & - & [99] \\
\hline Banana/Abaca & PROC & 97.28 & .56 & 82.849 & 0.221 & $1.09\left(\mathrm{~kJ} / \mathrm{m}^{2}\right)$ & - & [100] \\
\hline Flax/Jute & Polyester & 56.88 & 0.33 & 134.05 & 1.233 & $1000(\mathrm{~J} / \mathrm{m})$ & 14.8 & [89] \\
\hline Hemp/Flax & & 45 & 1.5 & 43 & 0.6 & $4\left(\mathrm{~kJ} / \mathrm{m}^{2}\right)$ & 5 & \\
\hline Hemp/Jute & Epoxy & 43 & 1.47 & 90 & 0.75 & $7\left(\mathrm{~kJ} / \mathrm{m}^{2}\right)$ & 4.6 & [101] \\
\hline Hemp/Jute/Flax & & 60 & 2 & 67 & 1.25 & $10\left(\mathrm{~kJ} / \mathrm{m}^{2}\right)$ & 6 & \\
\hline Jute/Sisal/Flax & Epoxy & 69.30 & 2.13 & 136.06 & 10.07 & - & - & [113] \\
\hline Jute/Pineapple & Epoxy & 70 & .82 & 240 & - & - & - & [102] \\
\hline
\end{tabular}

Notes: IP = Isopththalic Polyester; PROC = Phenolic resin of ortho-phthalic acid

\section{Conclusion}

Hybridization of natural and synthetic fiber with hand lay-up technique outperformed others in terms of operational complicacy. Several key concluding remarks of this review works are (i) epoxy and polyester were used mostly as matrix rather than other polymers, (ii) specimen with glass fiber at the outer surface exhibits better characteristics than other stacking sequences, (iii) mechanical properties increase linearly for upto certain amount of fiber content, then decreases gradually, (iv) samples with $0^{\circ}$ fiber orientation provided better results than other directional laminates or samples with chopped fiber, (v) surface modification of the fiber improved the mechanical properties of the composites, (vi) multiple fiber reinforced composites exhibit better quality than mono fiber-based product, (vii) jute fiber is most commonly used as one of the fibers in multiple fiber-based hybrid composites.

\section{Conflict of interest \& funding}

The author(s) declared no potential conflicts of interest with respect to the research, authorship, and/or publication of this article. The research work has been funded by Directorate of Research \& Extension, CUET, Bangladesh.

\section{Acknowledgements}

The author(s) acknowledged the funding authority, Directorate of Research \& Extension, CUET, Bangladesh for granting the project.

\section{References}

[1] Smith PA and Yeomans JA. Benefits of fiber and particulate reinforcement. Materials Science and Engineering, 2009, 2: 133-154.

[2] Hu J, Jahid MA, Harish Kumar, et al. Fundamentals of the Fibrous Materials. Handbook of Fibrous Materials, 2020: 1-36. https://doi.org/10.1002/9783527342587.ch1

[3] Yashas GTG, Sanjay MR, Parameswaranpillai J, et al. Natural Fibers as Sustainable and Renewable Resource for Development of Eco-Friendly Composites: A Comprehensive Review. Frontiers in Materials, 2019, 6: 226. https://doi.org/10.3389/fmats.2019.00226

[4] Mahir FI, Keya KN, Sarker B, et al. A brief review on natural fiber used as a replacement of synthetic fiber in polymer composites. Materials Engineering Research, 2019, 1(2): 86-97. https://doi.org/10.25082/MER.2019.02.007

[5] Shahzad A, Choudhry RS. Design and Manufacturing of Natural Fiber/Synthetic Fiber Reinforced Polymer Hybrid Composites. Handbook Composites Renew. Mater, 2017, 2: 411-447. https://doi.org/10.1002/9781119441632.ch34 
[6] Rao HR, Kumar MA and Reddy GR. Hybrid composites: Effect of fibers on mechanical properties. International Journal of Macromolecular Science, 2011, 1(1): 9-14.

[7] Mishra S, Mohanty AK, Drzal LT, et al. Studies on mechanical performance of biofibre/glass reinforced polyester hybrid composites. Composites science and technology, 2003, 63(10):13771385 . https://doi.org/10.1016/S0266-3538(03)00084-8

[8] Retnam BSJ, Sivapragash M and Pradeep P. Effects of fibre orientation on mechanical properties of hybrid bamboo/glass fibre polymer composites. Bulletin of Materials Science, 2014, 37(5): 10591064. https://doi.org/10.1007/s12034-014-0045-y

[9] Zamri MH, Akil HM, Bakar AA, et al. Effect of water absorption on pultruded jute/glass fiberreinforced unsaturated polyester hybrid composites. Journal of composite materials, 2012, 46(1): 51-61. https://doi.org/10.1177/0021998311410488

[10] Adeniyi AG, Onifade DV, Ighalo JO, et al. A review of coir fiber reinforced polymer composites. Composites Part B: Engineering, 2019, 176: 107305. https://doi.org/10.1016/j.compositesb.2019.107305

[11] Ramesh M and Nijanthan S. Mechanical property analysis of kenaf-glass fibre reinforced polymer composites using finite element analysis. Bulletin of Materials Science, 2016, 39(1): 147-157. https://doi.org/10.1007/s12034-015-1129-z

[12] Shanmugam D, Thiruchitrambalam M and Thirumurugan R. Continuous unidirectional palmyra palm leaf stalk fiber/glass-polyester composites: static and dynamic mechanical properties. Journal of Reinforced Plastics and Composites, 2014, 33(9): 836-850. https://doi.org/10.1177/0731684413518828

[13] Ramesh M and Sudharsan P. Experimental investigation of mechanical and morphological properties of flax-glass fiber reinforced hybrid composite using finite element analysis. Silicon, 2018, 10(3): 747-757. https://doi.org/10.1007/s12633-016-9526-5

[14] Chandramohan D, Murali B, Vasantha-Srinivasan P, et al. Mechanical, moisture absorption, and abrasion resistance properties of bamboo-jute-glass fiber composites. Journal of Bio-and TriboCorrosion, 2019, 5(3): 1-8. https://doi.org/10.1007/s40735-019-0259-z

[15] Sreekala MS, George J, Kumaran MG, The mechanical performance of hybrid phenol-formaldehydebased composites reinforced with glass and oil palm fibres. Composites science and technology, 2002, 62(3): 339-353. https://doi.org/10.1016/S0266-3538(01)00219-6

[16] Reddy GV, Naidu SV and Rani TS. A Study on Hardness and Flexural Properties of Kapok/Sisal Composites. Journal of Reinforced Plastics and Composites, 2009, 28(16): 2035-2044. https://doi.org/10.1177/0731684408091682

[17] Alam AKMM, Shubhra QT, Al-Imran G, et al. Preparation and characterization of natural silk fiber-reinforced polypropylene and synthetic E-glass fiber-reinforced polypropylene composites: a comparative study. Journal of composite materials, 2011, 45(22): 2301-2308. https://doi.org/10.1177/0021998311401082

[18] Bhoopathi R, Ramesh M, Kumar MN, et al. Studies on mechanical strengths of hemp-glass fibre reinforced epoxy composites. Materials Science and Engineering, 2018, 402(1): 012083). https://doi.org/10.1088/1757-899X/402/1/012083

[19] Sapuan SM, Lok HY, Isha, MR, et al. Mechanical properties of hybrid glass/sugar palm fibre reinforced unsaturated polyester composites. Chinese Journal of Polymer Science, 2013, 31(10): 1394-1403 https://doi.org/10.1007/s10118-013-1342-4

[20] Dhand V, Mittal G, Rhee KY, et al. A short review on basalt fiber reinforced polymer composites. Composites Part B: Engineering, 2015, 73:166-180. https://doi.org/10.1016/j.compositesb.2014.12.011

[21] Leong YW, Thitithanasarn S, Yamada K, et al. Compression and injection molding techniques for natural fiber composites. In Natural Fibre Composites, 2014: 216-232. https://doi.org/10.1533/9780857099228.2.216

[22] Tamakuwala VR. Manufacturing of fiber reinforced polymer by using VARTM process: A review. Materials Today: Proceedings, 2020. https://doi.org/10.1016/j.matpr.2020.11.102

[23] Asim M, Jawaid M, Saba N, et al. Processing of hybrid polymer composites-a review. Hybrid polymer composite materials, 2017: 1-22. https://doi.org/10.1016/B978-0-08-100789-1.00001-0

[24] Singh J, Kumar M, Kumar S, et al. Properties of glass-fiber hybrid composites: a review. PolymerPlastics Technology and Engineering, 2017, 56(5): 455-469. https://doi.org/10.1080/03602559.2016.1233271

[25] Ramesh M and Sudharsan P. Experimental investigation of mechanical and morphological properties of flax-glass fiber reinforced hybrid composite using finite element analysis. Silicon, 2018, 10(3): 747-757. https://doi.org/10.1007/s12633-016-9526-5 
[26] Ranganna H, Karthikeyan N, Nikhilmurthy V, et al. Mechanical and thermal properties of epoxy based hybrid composites reinforced with sisal/glass fibres. International Journal of Fiber and Textile Research, 2012: 2277-7156.

[27] Madhuri KS and Rao DHR. An Investigation of Mechanical and Thermal properties of Reinforced Sisal-Glass fibers epoxy hybrid composites. International Journal of Engineering Research, 2014, 2319: 6890 .

[28] Ashok Kumar M, Ramachandra Reddy G, Siva Bharathi Y, et al. Frictional coefficient, hardness, impact strength, and chemical resistance of reinforced sisal-glass fiber epoxy hybrid composites. Journal of Composite Materials, 2010, 44(26): 3195-3202. https://doi.org/10.1177/0021998310371551

[29] John K and Naidu SV. Tensile properties of unsaturated polyester-based sisal fiber-glass fiber hybrid composites. Journal of Reinforced Plastics and Composites, 2004, 23(17): 1815-1819. https://doi.org/10.1177/0731684404041147

[30] John K and Naidu SV. Effect of fiber content and fiber treatment on flexural properties of sisal fiber/glass fiber hybrid composites. Journal of reinforced Plastics and Composites, 2004, 23(15): 1601-1605.

https://doi.org/10.1177/0731684404039799

[31] John K and Naidu SV. Sisal fiber/glass fiber hybrid composites: the impact and compressive properties. Journal of reinforced plastics and composites, 2004, 23(12): 1253-1258. https://doi.org/10.1177/0731684404035270

[32] John K and Naidu SV. Chemical resistance of sisal/glass reinforced unsaturated polyester hybrid composites. Journal of reinforced plastics and composites, 2007, 26(4): 373-376. https://doi.org/10.1177/0731684406072524

[33] Naidu VNP, Kumar MA, Reddy GR, et al. Tensile \& flexural properties of sisal/glass fibre reinforced hybrid composites. International Journal of Macromolecular Science, 2011, 1(1): 19-22.

[34] Naidu VNP, Reddy GR, Kumar MA, et al. Compressive \& impact properties of sisal/glass fiber reinforced hybrid composites. International Journal of Fibre and Textile Research, 2011, 1(1): 11-14.

[35] Hashmi SAR, Naik A, Chand N, et al. Development of environment friendly hybrid layered sisalglass-epoxy composites. Composite Interfaces, 2011, 18(8): 671-683. https://doi.org/10.1163/156855412X626252

[36] PalanikumarK, Ramesh M and Hemachandra RK. Experimental Investigation on the Mechanical Properties of Green Hybrid Sisal and Glass Fiber Reinforced Polymer Composites. Journal of Natural Fibers, 2016, 13(3): 321-331. https://doi.org/10.1080/15440478.2015.1029192

[37] Samanta S, Muralidhar M and Sarkar S. Characterization of mechanical properties of hybrid bamboo/GFRP and jute/GFRP composites. Materials Today: Proceedings, 2015, 2(4-5): 1398-1405. https://doi.org/10.1016/j.matpr.2015.07.059

[38] Kushwaha PK and Kumar R. The studies on performance of epoxy and polyester-based composites reinforced with bamboo and glass fibers. Journal of Reinforced Plastics and Composites, 2010, 29(13): 1952-1962. https://doi.org/10.1177/0731684409342006

[39] Retnam BSJ and Sivapragash M. Pradeep P. Effects of fibre orientation on mechanical properties of hybrid bamboo/glass fibre polymer composites. Bulletin of Materials Science, 2014, 37(5): 10591064. https://doi.org/10.1007/s12034-014-0045-y

[40] Vaghasia B and Rachchh N. Evaluation of physical and mechanical properties of woven bamboo glass polyester hybrid composite material. Materials Today: Proceedings, 2018, 5(2): 7930-7936. https://doi.org/10.1016/j.matpr.2017.11.475

[41] Ramesh M, Palanikumar K and Reddy KH. Comparative evaluation on properties of hybrid glass fiber-sisal/jute reinforced epoxy composites. Procedia Engineering, 2013, 51: 745-750. https://doi.org/10.1016/j.proeng.2013.01.106

[42] Saravanan R and Gnanavel C. Synthesis and characterization of treated banana fibers and selected jute fiber based hybrid composites. Materials Today: Proceedings, 2020, 21: 988-992. https://doi.org/10.1016/j.matpr.2019.09.143

[43] Gujjala R, Ojha S, Acharya SK, et al. Mechanical properties of woven jute-glass hybrid-reinforced epoxy composite. Journal of Composite Materials, 2014, 48(28): 3445-3455. https://doi.org/10.1177/0021998313501924

[44] Ahmed KS and Vijayarangan S. Tensile, flexural and interlaminar shear properties of woven jute and jute-glass fabric reinforced polyester composites. Journal of materials processing technology, 2008, 207(1-3): 330-335.

https://doi.org/10.1016/j.jmatprotec.2008.06.038

[45] Sharmin K, Alam J and Dewan MW. Fabrication and characterization of jute/glass fiber reinforced epoxy hybrid composites, Journal of Mechanical Engineering, 2019, 49(2): 23-28.

[46] Ahmed KS, Vijayarangan S and Rajput C. Mechanical behavior of isothalic polyester-based untreated woven jute and glass fabric hybrid composites. Journal of reinforced plastics and composites, 2006, 25(15): 1549-1569. https://doi.org/10.1177/0731684406066747

[47] Shahzad A and Isaac D H. Fatigue properties of hemp and glass fiber composites. Polymer Composites, 2014, 35(10): 1926-1934. https://doi.org/10.1002/pc.22851 
[48] Trehan R, Singh S and Garg M. Optimization of mechanical properties of polyester hybrid composite laminate using Taguchi methodology-Part 1. Proceedings of the Institution of Mechanical Engineers, Part L: Journal of Materials: Design and Applications, 2015, 229(4): 263-273. https://doi.org/10.1177/1464420713509975

[49] Abdullah-Al-Kafi, Abedin MZ, Beg MDH, et al. Study on the mechanical properties of jute/glass fiber-reinforced unsaturated polyester hybrid composites: Effect of surface modification by ultraviolet radiation. Journal of Reinforced Plastics and Composites, 2006, 25(6): 575-588. https://doi.org/10.1177/0731684405056437

[50] Jayabal S, Natarajan U and Murugan M. Mechanical property evaluation of woven coir and woven coir-glass fiber-reinforced polyester composites. Journal of composite materials, 2011, 45(22): 22792285 . https://doi.org/10.1177/0021998311401080

[51] Jayabal S, Natarajan U and Sathiyamurthy S. Effect of glass hybridization and staking sequence on mechanical behaviour of interply coir-glass hybrid laminate. Bulletin of Materials Science, 2011, 34(2): 293-298. https://doi.org/10.1007/s12034-011-0081-9

[52] Bhagat VK, Biswas S and Dehury J. Physical, mechanical, and water absorption behavior of coir/glass fiber reinforced epoxy-based hybrid composites. Polymer composites, 2014, 35(5): 925-930. https://doi.org/10.1002/pc.22736

[53] Shrivastava R, Telang A, Rana RS, et al. Mechanical Properties of Coir/G Lass Fiber Epoxy Resin Hybrid Composite. Materials Today: Proceedings, 2017, 4(2): 3477-3483. https://doi.org/10.1016/j.matpr.2017.02.237

[54] Kumar NM, Reddy GV, Naidu SV, et al. Mechanical properties of coir/glass fiber phenolic resin-based composites. Journal of reinforced plastics and composites, 2009, 28(21): 2605-2613. https://doi.org/10.1177/0731684408093092

[55] Sharba MJ, Leman Z, Sultan M T, et al. Effects of kenaf fiber orientation on mechanical properties and fatigue life of glass/kenaf hybrid composites. BioResources, 2016, 11(1): 1448-1465. https://doi.org/10.15376/biores.11.1.2665-2683

[56] Sharba MJ, Leman Z, Sultan MTH, et al. Tensile and compressive properties of woven kenaf/glass sandwich hybrid composites. International Journal of Polymer Science, 2016 https://doi.org/10.1155/2016/1235048

[57] Sharba MJ, Leman Z, Sultan MTH, et al. Monotonic and fatigue properties of kenaf/glass hybrid composites under fully reversed cyclic loading. Materials Science and Engineering, 2015, 100(1): 012055 . https://doi.org/10.1088/1757-899X/100/1/012055

[58] Rozali NA, Abu Bakar MB, Masri MN, et al. Mechanical and water absorption properties of hybrid Kenaf/Glass fibre mat reinforced unsaturated polyester composites. In Materials Science Forum, 2017, 888: $228-233$. https://doi.org/10.4028/www.scientific.net/MSF.888.228

[59] Velmurugan R and Manikandan V. Mechanical properties of palmyra/glass fiber hybrid composites. Composites Part A: applied science and manufacturing, 2007, 38(10): 2216-2226. https://doi.org/10.1016/j.compositesa.2007.06.006

[60] Sravya NP and Sivaganesan S. Mechanical Characterization of Palmyra-and S Glass Fibre-Reinforced Hybrid Polymer Composites. In Advances in Industrial Automation and Smart Manufacturing, 2021: 1087-1096. https://doi.org/10.1007/978-981-15-4739-3_93

[61] Karthikeyan S, Bala Kumaran A, Mohan NS, et al. Evaluation of Mechanical Properties of Palmyra Fruit Fiber and Glass Fiber Hybrid Composites, 2017, 3(3): 1079-1084.

[62] Meenakshi CM and Krishnamoorthy A. Preparation and mechanical characterization of flax and glass fiber reinforced polyester hybrid composite laminate by hand lay-up method. Materials Today: Proceedings, 2018, 5(13): 26934-26940. https://doi.org/10.1016/j.matpr.2018.08.181

[63] Santulli C, Janssen M and Jeronimidis G. Partial replacement of E-glass fibers with flax fibers in composites and effect on falling weight impact performance. Journal of materials science, 2005, 40(13): 3581-3585. https://doi.org/10.1007/s10853-005-2882-y

[64] Gupta KM. Experimental investigation of the behavior of dual fiber hybrid composite under different stacking sequence. In 17th International Conference on Composite Materials, 2009.

[65] Kumar SN, Venkatesh D, Subbaratnam B, et al. Mechanical Testing and Numerical Analysis of Flax/Glass Epoxy Hybrid Composite Material. In IOP Conference Series: Materials Science and Engineering, 2020, 998(1): 012032.

https://doi.org/10.1088/1757-899X/998/1/012032

[66] Wang H, Yang L, Wu H. Study on mechanical and thermomechanical properties of flax/glass fiber hybrid-reinforced epoxy composites. Polymer Composites, 2020, 42(2): 714-723. https://doi.org/10.1002/pc.25860

[67] Joseph S, Sreekala MS and Koshy P. Mechanical properties and water sorption behavior of phenolformaldehyde hybrid composites reinforced with banana fiber and glass fiber. Journal of applied polymer science, 2008, 109(3): 1439-1446. https://doi.org/10.1002/app. 27425 
[68] Laly Pothan A, Thomas S and George J. Tensile and impact properties of banana fibre/glass fibre hybrid polyester composites. ICCM, 2012.

[69] Batu T and Lemu H G. Investigation of mechanical properties of false banana/glass fiber reinforced hybrid composite materials. Results in Materials, 2020, 8: 100152 https://doi.org/10.1016/j.rinma.2020.100152

[70] Saravanan R and Gnanavel C. Synthesis and characterization of treated banana fibers and selected jute fiber based hybrid composites. Materials Today: Proceedings, 2020, 21: 988-992. https://doi.org/10.1016/j.matpr.2019.09.143

[71] Prashanth A, Suresh D and Reddy EV. Experimental Investigation of Hybrid Hemp-Glass Fiber Reinforced Epoxy Composite, International Journal of Innovative Research \& Studies, 2018, 8(9): 416-423.

[72] Unki HN, Shivanand HK and Vidyasagar HN. Investigation of mechanical properties of hemp/glass fiber reinforced nano clay hybrid composites. In AIP Conference Proceedings, 2018, 1943(1): 020114. https://doi.org/10.1063/1.5029690

[73] Shahzad A. Impact and fatigue properties of hemp-glass fiber hybrid biocomposites. Journal of Reinforced Plastics and Composites, 2011, 30(16): 1389-1398. https://doi.org/10.1177/0731684411425975

[74] Devi LU, Bhagawan SS and Thomas S. Dynamic mechanical analysis of pineapple leaf/glass hybrid fiber reinforced polyester composites. Polymer composites, 2010, 31(6): 956-965. https://doi.org/10.1002/pc.20880

[75] Idicula M, Boudenne A, Umadevi L, et al. Thermophysical properties of natural fibre reinforced polyester composites. Composites science and technology, 2006, 66(15): 2719-2725. https://doi.org/10.1016/j.compscitech.2006.03.007

[76] Silva RV, Aquino EMF, Rodrigues LPS, et al. Curaua/glass hybrid composite: the effect of water aging on the mechanical properties. Journal of reinforced plastics and composites, 2009, 28(15): 1857-1868. https://doi.org/10.1177/0731684408090373

[77] Reddy EVS, Rajulu AV, Reddy KH, et al. Chemical resistance and tensile properties of glass and bamboo fibers reinforced polyester hybrid composites. Journal of reinforced plastics and composites, 2010, 29(14): 2119-2123. https://doi.org/10.1177/0731684409349520

[78] Reddy GV, Rani TS, Rao KC, et al. Flexural, Compressive, and Interlaminar Shear Strength Properties of Kapok/Glass Composites. Journal of Reinforced Plastics and Composites, 2009, 28(14): 1665 1677. https://doi.org/10.1177/0731684408090362

[79] Reddy GV, Naidu SV and Rani TS. Kapok/glass polyester hybrid composites: Tensile and hardness properties. Journal of Reinforced Plastics and Composites, 2008, 27(16-17): 1775-1787. https://doi.org/10.1177/0731684407087620

[80] Reddy GV, Naidu SV and Rani TS. Impact properties of kapok based unsaturated polyester hybrid composites. Journal of Reinforced Plastics and Composites, 2008, 27(16-17): 1789-1804. https://doi.org/10.1177/0731684407087380

[81] Priya SP and Rai SK. Mechanical performance of biofiber/glass-reinforced epoxy hybrid composites. Journal of industrial textiles, 2006, 35(3): 217-226. https://doi.org/10.1177/1528083706055754

[82] Yang Y, Zhao D, Xu J, et al. Mechanical and optical properties of silk fabric/glass fiber mat composites: an artistic application of composites. Textile Research Journal, 2018, 88(8): 932-945. https://doi.org/10.1177/0040517517690621

[83] Safri SN, Sultan MT, Saba N, et al. Effect of benzoyl treatment on flexural and compressive properties of sugar palm/glass fibres/epoxy hybrid composites. Polymer Testing, 2018, 71: 362-369. https://doi.org/10.1016/j.polymertesting.2018.09.017

[84] Sapuan SM, Aulia HS, Ilyas RA, et al. Mechanical properties of longitudinal basalt/woven-glassfiber-reinforced unsaturated polyester-resin hybrid composites. Polymers, 2020, 12(10): 2211. https://doi.org/10.3390/polym12102211

[85] Patel N, Patel K, Gohil P, et al. Investigations on mechanical strength of hybrid basalt/glass polyester composites. International Journal of Applied Engineering Research, 2018, 13(6): 4083-88.

[86] Ramesh M, Palanikumar K and Reddy KH. Mechanical property evaluation of sisal-jute-glass fiber reinforced polyester composites. Composites Part B: Engineering, 2013, 48: 1-9. https://doi.org/10.1016/j.compositesb.2012.12.004

[87] Ramesh M, Palanikumar K and Reddy KH. Influence of fiber orientation and fiber content on properties of sisal-jute-glass fiber-reinforced polyester composites. Journal of Applied Polymer Science, 2016, 133(6): 42968. https://doi.org/10.1002/app.42968

[88] Ramnath BV, Kokan SJ, Raja RN, et al. Evaluation of mechanical properties of abaca-jute-glass fibre reinforced epoxy composite. Materials \& Design, 2013, 51: 357-366. https://doi.org/10.1016/j.matdes.2013.03.102

[89] Ramnath BV, Manickavasagam VM, Elanchezhian C, et al. Determination of mechanical properties of intra-layer abaca-jute-glass fiber reinforced composite. Materials \& Design, 2014, 60: 643-652. https://doi.org/10.1016/j.matdes.2014.03.061 
[90] Ramnath BV, Sharavanan R, Chandrasekaran M, et al. Experimental determination of mechanical properties of banana jute hybrid composite. Fibers and polymers, 2015, 16(1): 164-172. https://doi.org/10.1007/s12221-015-0164-0

[91] Rajesh M and Pitchaimani J. Mechanical and dynamic mechanical behaviour of novel glass-natural fibre intra-ply woven polyester composites. Sādhanā, 2017, 42(7): 1215-1223. https://doi.org/10.1007/s12046-017-0676-y

[92] Parandaman P and Jayaraman M. Experimental investigation on the mechanical properties of jute/sisal/glass and jute/banana/glass hybrid composite materials. European Journal of Applied Sciences, 2015, 7(3): 138-44

[93] Chandramohan D, Murali B, Vasantha-Srinivasan P, et al. Mechanical, moisture absorption, and abrasion resistance properties of bamboo-jute-glass fiber composites. Journal of Bio-and TriboCorrosion, 2019, 5(3): 1-8. https://doi.org/10.1007/s40735-019-0259-z

[94] Pani PR, Nayak RK, Routara BC,et al. Flexural and specific wear rate of seawater aged bamboo, jute and glass fiber reinforced polymer hybrid composites. Materials Today: Proceedings, 2019, 18: 3409-3414.

https://doi.org/10.1016/j.matpr.2019.07.268

[95] Bhoopathi R, Deepa C, Sasikala G, et al. Experimental investigation on mechanical properties of hemp-banana-glass fiber reinforced composites. Applied Mechanics and Materials, 2015, 766: $167-$ 172. https://doi.org/10.4028/www.scientific.net/AMM.766-767.167

[96] Bhoopathi R, Ramesh M and Deepa C. Fabrication and property evaluation of banana-hemp-glass fiber reinforced composites. Procedia Engineering, 2014, 97: 2032-2041. https://doi.org/10.1016/j.proeng.2014.12.446

[97] Bhoopathi R, Ramesh M, Rajaprasanna R, et al. Physical properties of glass-hemp-banana hybrid fiber reinforced polymer composites. Indian Journal of Science and Technology, 2017, 10(7): 1-7. https://doi.org/10.17485/ijst/2017/v10i7/103310

[98] Chaithanyan C, Venkatasubramanian H, Raghuraman, DS, et al. Evaluation of mechanical properties of coir sisal reinforced hybrid composites using isophthalic polyester resin. International Journal of Innovative Research in Science, Engineering and Technology, 2013, 2(12): 7480-7487.

[99] Venkatasubramanian H, Chaithanyan C, Raghuraman S, et al. Evaluation of mechanical properties of abaca-glass-banana fiber reinforced hybrid composites. International Journal of Innovative Research in Science, Engineering and Technology, 2014, 3(1): 8169-8177.

[100] Venkatasubramanian H and Raghuraman S. Mechanical behaviour of abaca-glass-banana fibre reinforced hybrid composites. Journal of Engineering Science and Technology, 2015, 10(8): 958-971.

[101] Chaudhary V, Bajpai PK and Maheshwari S. Studies on mechanical and morphological characterization of developed jute/hemp/flax reinforced hybrid composites for structural applications. Journal of natural fibers, 2018, 15(1): 80-97. https://doi.org/10.1080/15440478.2017.1320260

[102] Reddy MI, Kumar MA and Raju CRB. Tensile and flexural properties of jute, pineapple leaf and glass fiber reinforced polymer matrix hybrid composites. Materials today: proceedings, 2018, 5(1) 458-462. https://doi.org/10.1016/j.matpr.2017.11.105

[103] Reddy MI, Varma UP, Kumar IA, et al. Comparative evaluation on mechanical properties of jute pineapple leaf fiber and glass fiber reinforced composites with polyester and epoxy resin matrices. Materials Today: Proceedings, 2018, 5(2): 5649-5654. https://doi.org/10.1016/j.matpr.2017.12.158

[104] Rana RS, Rana S and Purohit R. Characterization of properties of epoxy sisal/glass fiber reinforced hybrid composite. Materials Today: Proceedings, 2017, 4(4): 5445-5451. https://doi.org/10.1016/j.matpr.2017.05.056

[105] Mishra S, Mohanty AK, Drzal LT, et al. Studies on mechanical performance of biofibre/glass reinforced polyester hybrid composites. Composites science and technology, 2003, 63(10): 1377 1385. https://doi.org/10.1016/S0266-3538(03)00084-8

[106] Latha PS, Rao MV, Kumar VK, et al. Evaluation of mechanical and tribological properties of bamboo-glass hybrid fiber reinforced polymer composite. Journal of Industrial Textiles, 2016, 46(1): 3-18. https://doi.org/10.1177/1528083715569376

[107] Rao HR, Rajulu AV, Reddy GR, et al. Flexural and compressive properties of bamboo and glass fiber-reinforced epoxy hybrid composites. Journal of Reinforced Plastics and Composites, 2010, 29(10): 1446-1450. https://doi.org/10.1177/0731684409105077

[108] Rafiquzzaman M, Islam M, Rahman H, et al. Mechanical property evaluation of glass-jute fiber reinforced polymer composites. Polymers for Advanced Technologies, 2016, 27(10): 1308-1316. https://doi.org/10.1002/pat.3798

[109] Sanjay MA and Yogesha B. Studies on mechanical properties of jute/E-glass fiber reinforced epoxy hybrid composites. Journal of Minerals and materials characterization and engineering, 2016, 4(1): $15-25$. https://doi.org/10.4236/jmmce.2016.41002 
[110] Velmurugan R and Manikandan V. Mechanical properties of glass/palmyra fiber waste sandwich composites, Indian Journal of Engineering \& Materials Sciences, 2005, 12: 563-570.

[111] Kumar NV, Krishna BS and Chandrika NS. Evaluation of properties of glass-banana-fiber reinforced hybrid fiber polymer composite. Materials today: Proceedings, 2019, 18: 2137-2141. https://doi.org/10.1016/j.matpr.2019.06.648

[112] Hariharan ABA and Khalil HA. Lignocellulose-based hybrid bilayer laminate composite: Part I-Studies on tensile and impact behavior of oil palm fiber-glass fiber-reinforced epoxy resin. Journal of Composite Materials, 2005, 39(8): 663-684. https://doi.org/10.1177/0021998305047267

[113] Benkhelladi A, Laouici $\mathrm{H}$ and Bouchoucha A. Tensile and flexural properties of polymer composites reinforced by flax, jute and sisal fibres. The International Journal of Advanced Manufacturing Technology, 2020, 108: 895-916. https://doi.org/10.1007/s00170-020-05427-2

[114] Khalil HA, Hanida S, Kang CW, et al. Agro-hybrid composite: the effects on mechanical and physical properties of oil palm fiber (EFB)/glass hybrid reinforced polyester composites. Journal of Reinforced Plastics and Composites, 2007, 26(2): 203-218. https://doi.org/10.1177/0731684407070027

[115] Karina M, Onggo H, Abdullah AD, et al. Effect of oil palm empty fruit bunch fiber on the physical and mechanical properties of fiber glass reinforced polyester resin. Journal of Biological Sciences, 2008, 8(1): 101-106.

https://doi.org/10.3923/jbs.2008.101.106 